\title{
Strategic Implication of Rising Global Food Security Crisis
}

\author{
Anthony Ikhide Osawe \\ Department of Geography \& Environmental Management, Ambrose Alli University, \\ Ekpoma, Edo Nigeria
}

\begin{abstract}
The study investigated the rising global food security crisis. Emphasis was placed on the strategic implication of this menace, and this was done with a focus on Nigeria. To carry out the study effectively, secondary data was used. The rising global food security crisis is occasioned by rising global food prices. This is also accompanied by scarcity of staple food sources. It was discovered that there was indeed a rising global food security crisis, and that the strategic implication of this is rarely investigated. Causes of global food security crisis include global high cost of energy, use of bio fuel based energy, increase in global population and demand for food, climate change, under investment in agriculture production, armed conflict corruption and bad government in Africa. The strategic implication of food security included general insecurity health problems migration environmental degradation etc. The outbreak of COVID-19 brought to the knowledge of all that a combination of short-term responses and long term investment driver of foodinsecurity. It was concluded that there is indeed a rising global food security crisis. It was therefore recommended that the United States (U.S.) and other donor countries should make agriculture and rural development is priority in its internal assistance programmes. It was also recommended that since global security challenges, such as terrorism are linked to food security crisis and poverty in general, current international and local efforts should include measures that put food on every citizens' table by way of frustrating and eradication of terrorism, recommendation also includes the development of practical strategies to improve agricultural practices such as food storage should be researched and developed being a major challenge faced by developing countries.
\end{abstract}

Keywords: Food Security, Poverty, Food storage, rising prices, insecurity, global health and armed conflicts.

DOI: $10.7176 / \mathrm{PPAR} / 11-4-05$

Publication date:May $31^{\text {st }} 2021$

\section{INTRODUCTION}

There is a global food security crisis. The U.N food and Agriculture Organization (FAO) was determined that since the 1990, close 2 billion people across the globe suffer from hunger and chronic nutrient deficiencies (FAO, 2006). Recent estimate by the FAO shows that a total of 925 million people are currently undernourished in the world. Although this number declined between 2009 and 2010 due to the recovery in economic growth, the number of hungry people remains higher than what was obtainable before the 2007/2008 food crisis. The FAO also estimates that in sub-Saharan Africa, about 30 percent (which equals 239 million people are undernourished (FAO, 2010). Africa has the largest proportion among the developing regions.

The crisis is an outcome of the recent extraordinary increases in the price of food, which was also coupled with shortage and diminishing food stocks. This reduced access to food for many people (particularly the poor) in many developing countries. Although the consequences of this crisis are severe in low income food-importing counties, especially in the least developed countries (LDCs), its impact are also even in the larger developing economies such as India and China, as well as in some Latin American countries (UNTAD, 2008).

The challenges of food security are real for both the developing nations and the developed world. The difference between food security within the two divide lies in the severity and proportion of the population affected. In the developed nations the problem is alleviated by providing targeted food security interventions, including food aid in the form of direct food relief, food stamps or indirectly through subsidized food production (Nwaniki, 2009). These facilities are noticeably lacking in the developing countries, particularly in Africa.

This does not mean that developed countries are immune to the negative consequences of crisis, as rising food prices have added to inflationary or poverty tensions already being felt as result of rising energy prices and crashes in financial and housing markets of these countries. Most critical is the urgent hunger needs in over 37 developing countries, as identified by the Food and Agriculture Organization of the United Nations (FAO) 20 of which are LDCs. The food crisis can provide an opportunity in the sense that higher food prices should be beneficial for many farmers in developing countries. This is because these foods can be exported to other countries were prices are higher for such food item.

Africa is worst off because of the inability of its people to gain access to food due to poverty. Sub-Saharan Africa in particular continues to lag behind in this regard. Other factors that have contributed include the high prevalence of HIV/AIDs; civil war, strive and poor governance; frequent drought and famine; and agricultural dependency on the climate and environment, food security on the continent has worsened since 1970 and the prevalence of malnutrition within the continent varies by region. The proportion of the malnourished population 
has remained within the 33 to 35 percent range in Sub-Saharan Africa. It is lowest in Northern Africa (4 percent) and highest in Central Africa (40 percent)(Rosegrant, et al. 2005). In Nigeria, the recent flooding that affected about twenty states has brought to the forefront, the concept of food security. The federal government on the 27 of September raised the alarm over an imminent national food security crisis as a result of the flooding in some parts of the country (Adepegba, 2012).

Attention needs to be given to global food security challenges because it will become a greater challenge with time. This is because world population will continue to grow (particularly in middle-income Countries). Additionally, increasing threats from climate change will continue to threaten global agricultural practices, while the competition for energy resources from the advanced countries will continue to increase, more importantly, studies in food security are most focused on policy option without much attention paid to the security aspect of the challenge.

For example, the United Nation Conference on trade and development (UNTAD) addressed the global food crisis using key trade, investment and commodity policies as a way to ensuring sustainable food security and alleviating poverty (UNTAD, 2008). The study which took a trade and development perspective did not give attention to the strategic implication of food security. Another study by Michiel Van Dijk looks at African regional trade, regional integration agreements (RIAs) and the implications of this food security (Van Dijk, 2011). This study like many others are based on the interactions between policy and trade, lacking an essential strategy based outlook of the problem of food security. To adequately study this problem, the following research question and objectives of study are raised.

\subsection{Research Questions}

i. What is the strategic implication of global food insecurity?

ii. What are the implications of food security for Nigeria?

iii. What is the solution to the rising global food security?

\subsection{Objective of Research}

i. To determine the strategic implications of global food insecurity;

ii. to understand the implication of food security for Nigeria; and

iii. to proffer solutions to the rising threat of global food security

\subsection{Method}

Secondary data were used to carry out this study. It was sourced from credible research materials such as journals and books from bookshops and libraries of institutions and universities across the country. The internet was also an invaluable source of e-book and journals deployed for this work.

\section{Literature Review}

The concept of food security originated during the mid-1970s, when the 1974 world food conference defined it basically in terms of food supply, with respect o availability and price stability of basic foodstuffs at the international and national levels. According to that conference food security is: "Availability at all times of adequate world food supplies of basic foodstuffs to sustain a steady expansion of food consumption and to offset fluctuation in production and prices"(World Food Conference, 1974). This definition reflected the initial focus of global concerns of 1974, which was on the volume and stability of food supplies. By 1983 FAO expanded its concept to include securing access by vulnerable people to available supplies, implying that attention should be balanced between the demand and supply side of the food security equation. Food security was thus defined as: ensuring that all people at all ties have both physical and economic access to the basic food that they need FAO, 1983; Osawe, 2015). The Committee on World Food Security CFS (2012) notes that Food security exists when all people, at all times, have physical, social and economic access to sufficient, safe and nutritious food that meets their dietary needs and food preferences for an active and healthy life. The four pillars of food security are availability, access, utilization and stability. The nutritional dimension is integral to the concept of food security and to the work of CFS.

By the mid-1990s food security became a significant source of concern, not only on the level of the state, but globally. However, access now involved sufficient food, indicating continuing concern with protein-energy malnutrition. But the definition broadened to incorporate food safety and also nutritional balance, reflecting concern about food composition and minor nutrient requirements for an active and healthy life. Food preference, socially or culturally determined, now became a consideration. The potentially high degree of context specificity implies that the concept had both lost is simplicity and was not itself a goal, but an intermediating set of actions that contribute to an active and healthy life (in Shaw, 2007) consequently, the World Food Summit of 1996 defined Food security, at the individual household, national regional and global levels (is achieved) when all people, at all times, have physical and economic access to sufficient, safe and nutritious food to meet their 
dietary needs and food preferences for an active and healthy life.

This definition was again refined in the state of food insecurity 2001: "Food security is a situation that exists when all people, at all times have physical, social and economic access to sufficient safe and nutrition food that meets their dietary needs and food preferences for an active and healthy life." (www.fao.org ) in summary, the world food summit insist that food security can only "exist when all people at all times have physical and economic access to sufficient, safe and nutritious food that meets their dietary needs and food preference for an active and healthy life (FAO, 2006; CSF, 2005). This became the widely accepted definition of food security because it emphasized the multidimensional nature of food security of and includes food availability, access food use and stability

2.1 Food availability: The availability of sufficient quantities of food of appropriate quality, supplied through domestic production or imports (including food aid).

2.2 Food access: Access by individuals to adequate resources (entitlements) for acquiring appropriate foods for a nutritious diet. Entitlements are defined as the set of all commodity bundles over which over which a person can establish command given the legal, economic the legal, political economic and social arrangement of the community in which they live (including traditional right such as access to common resources).

2.3 Utilization: Utilization of food through adequate dies, clean water, sanitization and health care to reach a state of nutritional well-being where all physiological needs are met. This brings out the importance of non-food inputs in food security.

2.4 Stability: to be food secure, a population household or individual must have access to adequate food at all times. They should not risk losing access to food as a consequence of sudden shocks (e.g. an economic or climatic crisis) or cyclical events (e.g. seasonal food insecurity). The concepts of stability can therefore refer to both the availability and access dimensions of food security.

Although an ethical and human dimension of food security was first recognized in the UN Declaration of human rights in 1948, it only came in into focus in recent time. About 40 countries have the right to food enshrined in their constitution and Food and Agricultural Organization hope that the right to food could become judicial in over 54 countries (FAO, 2006).

As Van Dijk noted, different countries can choose between two forms of food security policy. The first option is pursue a strategy of food self-sufficiency, requiring all food needs, be fulfilled by means of domestic production. The second option is adopted a strategy of self-reliance. This option argues that availability of food is most important and must be either produced domestically or sourced by means of international trade. Additionally, Van Dijk argues that Most economic would that self-sufficiency is not an efficient and viable food security policy as it fails to acknowledge potential gains of trade that are created by international differences in production factor endowments, technology and environmental factors such as infrastructure and climate (Van Dijk, 2013)

However, the most important element of food security is a person's access to food, not the extent to which food commodities are produced in a country or region. Food security is therefore predominantly a poverty issue, and governments should therefore adopt a self-reliance strategy to achieve food security (CSF, 2012).

2.5 The right to adequate food: In the International Covenant on Economic, Social and Cultural Rights (ICESCR) xviii of 1966, (http://www2.ohchr.org/english/law/cescr.htm States recognized: “...the right of everyone to an adequate standard of living for himself and his family, including adequate food (...) and to the continuous improvement of living conditions" (Article 11, par. 1) as well as "the fundamental right of everyone to be free from hunger" (Article 11, para. 2). The United Nations Committee on Economic, Social, and Cultural Rights (OHCHR)xix has given a definition of the right to adequate food: The right to adequate food is realized when every man, woman and child, alone or in community with others, has physical and economic access at all times to adequate food or means for its procurement. The core content of the right to adequate food implies (http://www2.ohchr.org/english/bodies/cescr/comments.htm ) the availability of food in a quantity and quality sufficient to satisfy the dietary needs of individuals, free from adverse substances, and acceptable within a given culture (and) the accessibility of such food in ways that are sustainable and that do not interfere with the enjoyment of other human rights.

According to IFPRI (2014) food insecurity, malnutrition and poverty are the most serious global challenges of the 21 st century. Approximately half of the world's population lives below the poverty line. While 805 million people across the world are facing extreme hunger, in spite of of the fact that the world food production has doubled during the last three decades (FAO, 2014). More than three billion People over the world live on less than $\$ 2.50$ a day. Whereas 1.3 billion people in the entire world face extreme poverty and survive on less 
than $\$ 1.25$ a day. One billion children are victims of poverty worldwide. According to UNICEF, 22,000 children die each day due to undernourishment. More than 750 million people are in shortage of access to fresh drinking water. More than 2 billion people are facing micronutrient deficiencies (FAO, 2014). International organizations are afraid that this may increase considerably due to global demographic stresses, for example, shrinking cultivatable land, increasing water insufficiency, environmental changes (IFPRI, 2016). Despite the efforts made, situation in less developed countries is unsatisfactory (IFPRI, 2016). They are suffering from a greater prevalence of poverty and food insecurity (IFPRI, 2016). Food insecurity is a great problem in South Asia and Sub-Saharan Africa. It is found that in both regions, energy intake deficiency incidence is very much closer to each other i.e. 51 percent in South Asia, 57 percent in Sub-Saharan Africa (Wiesemann, 2007).

\section{Theoretical Framework}

A number of factors are implicated for the rising global food security crisis. They include bio fuel consumption, high oil prices, environmental degradation, population and growing middle class, poor harvest etc. the term 'perfect storm' $(F A O, 2006 \mathrm{e})$ is the framework used to explain the combined effects of these factors.

Speaking on the phenomenon of 'perfect storm; Thomas Molony and James Smith (2010) explained that combined influences among them increased oil prices, weather related shortfalls, poor harvest global population growth, and economic growth in emerging economies will requires a revolution in the social and natural sciences concerned with food production.

The new record food prices have serious implications, especially for nations with high rate of inequality and poverty. This is made more dangerous as we will almost certainly face a potentially catastrophic, global scale famine in the next couple of decades. To further make matters worse, there are now over seven billion people on our planet earth, which is driven largely due to the emergence of two separate technologies. Firstly, in the more advanced countries, cheap fossil fuels have enabled us to glow food on industrial scales. About 10 calories of fossil fuel energy are required to produce one calorie of food. A century ago each calorie of energy expended two calories of food. Secondly, advances in health care, primarily antibiotics and vaccines, have increased human life-spans (Molony et al., 2010). The burning of this fossil fuel also has impact on environment degradation

Diminishing energy supplies and high cost of fossil fuel has encouraged wealthy governments to promote the production and consumption of 'bio fuels'. These are produced from agricultural resources such as sugar cane, beet, maize, soy, and oil crops such as palm oil and canola. This focuses on bio fuels which opponents' prefer to call agro-fuels because of their propensity to divert scarce agricultural production from food production to growing fuel crops. This has immense negative impact on food security, also to be factored into food security problems are increased consumption of meat, which resulted from the increase in wealth of the population. Grazing area for meat production, mainly beef, use more than a quarter of ice-free land surface. Additionally, more than a third of all cropland is used to grow crops to feed livestock. These are produced using energy intensive, industrial agricultural practice (Charles J. Godfray et al., 2010). These combined problems have been explained under the framework of 'perfect storm' As Charles Godfray, et al put it, "Any optimism must be tempered by the enormous challenges of making food production sustainable while controlling greenhouse gas emission and conserving dwindling water supplies, as well as meeting the millennium Development Goal of ending hunger.

They also insist that we must avoid the temptation to further sacrifice Earth's already hugely depleted biodiversity for easy gains in food production, not only because biodiversity provides many of the public goods on which mankind relies but also because we do not have the right to deprive future generations of its economic and cultural benefits. Finally, they explained that "together, these challenges amount to a perfect storm.

Flowing from the above challenges, John Beddington (England's chief scientific advisor), predicting a "perfect storm" scenario according to him "It is predicted that by 2030 the world will need to produce around 50 percent more food and energy, together with 30 per cent more fresh water, whilst mitigating and adapting to climate change. This threatens to create a perfect storm of global events... There's not going to be a complete collapse, but things will start getting really worrying if we don't tackle these problems" (Bedington, 2009). The elements of the "perfect storm" scenario are:

- Consistent with earlier demographic projections, global population have increased from 6.8 billion to 8.3 billion.

- Demand for food has grown by 40 percent, but supplies have not kept up with demand. World grain reserves are empty. The FAO warns that bad harvest and grain export embargoes are pushing 200 million people to "the brink of starvation."

- Demand for energy has grown by 45 percent, but supplies recent years have to keep up; the resulting scarcity has pushed energy process to record highs.

- Global demand for water has grown by close 30 percent. Water conservation measures have helped, but close to four billion people are now livings in an area of high water stress. 
- Efforts to reduce greenhouse gas emissions have fallen far short of the pledges made in 2010. Climate change is more evident, and the concentration of greenhouse gas emissions is dangerously close to the $450 \mathrm{ppm}$ level that could trigger the worst effects of climate change

- Shortage of food, energy and water are increasing the number of failed states and racketing up international tension.

This will however continue to generate arguments such as is the perfect storm a likely scenario for 2030? Is it too pessimistic or too optimistic? Meanwhile what we can do is to set target to counter change, energy consumption and food security.

\section{CAUSES OF GLOBAL FOOD CRISIS}

Many factors are responsible for the root causes of global food security crisis. These factors are complex, interlocked, and even multidimensional in nature. From some of the causes of global food crisis, it becomes easy to see why even the developed countries are not immune food security crisis. Some of the causes of food security include the following:

\subsection{High cost of global energy}

Soaring cost of global energy is a major factor in international and local cause of food security crisis. This is a major factor because it contributes by increasing the cost in agricultural production and transportation, as equipment used to run farms and transport farm products to points of service are fun by energy. These impacts on food crisis on all points across the farm-to-market chain (Daviron and Douillet, 2014)

\subsection{Use of Bio-fuel Based Energy}

Recently, there has been a call for the production and use of effective bio-energy. The demand for bio-fuel (or biogas) is occasioned by the high and rising oil price, while preferential tariffs, subsidies, and mandates contributes to the rise of American and European producer for biofuel crops. Biogas typically refers to gas produced by the biographical breakdown of organic matter in the absence of oxygen (http.//tmcfluidsystems.com). The bio-energy is generated from food grains and other food associated material. The increase production of bio-fuel based on food grains contributed to global food price increases. It has been estimated that the impact of the bio-energy on food security crisis vary, ranging from 3 percent to 65 percent (FAO, 2008). This is not a concern for only developed countries. For example, Tanzania spends about US. 1.31.6 billion per year on oil imports, which amounts to some 25 percent of its total foreign exchange earnings.

The bio-fuel business is so good that certain countries such as Brazil, Mexico, and Malaysia are key players among bio-fuels exporters some African countries most notably Angola Ethiopia, Kenya and South Africa, are considering joining the ranks of substantial exporters of bio-fuels. In line with this, Accordingly, a growing number of African countries among them Malawi, Mail, Mauritius, Nigeria, Senegal, South Africa, Zambia, and Zimbabwe have now enacted new pre-bio-fuel national strategies the World Bank even funded National Bio-fuel policy and Strategy for Mozambique ( Mitchell, 2011, Sekoai, 2016).

This is indeed a global phenomenon that affects markets for wheat maize, sugar, oil seeds cassava, palm oil, etc. According to Centre for strategic and International Studies (CSIS) (2019), "the shared dilemma for Europe and the U.S is how to respond responsibly and effectively to intensifying pressures to promote food and fuel security simultaneously.

The United States is a powerful actor among the fossil fuel-importing nations according to the UN, World Bank, and international Monetary Fund (IMF), bio-fuel is the greatest culprit responsible for the food crisis. As an example the use of corn to produce bioethanol in the United States has increased from 6 percent of total corn production to 23 percent over the last three years. The obviously has contributed greatly to tightening food supplies and rising food prices.

\subsection{Increase in Global Population and Demand for Food}

Global population continue to grow. This make a enormous demand on food produced because agricultural practice is not calculated to match the growing population. Demand for cereal grains has outstripped supply over the past several years, generating a global imbalance and a decline in surpluses. China and India continue to experience high demand for cereal and other food material. This results from their growing middle classes, which causes increase strain on global supplies, China with a current population of 1.3 billion has almost doubled its consumption of meat, fish, and dairy products since 1990 as over 200 million people have been lifted out of poverty (Alexandratos, 2012).

It is therefore expected that population increase will be coupled with increasing prosperity. Thus, economic advances projected for the developing World will help lift millions from poverty, and on the other respect will add to the challenges. As income rise in developing and middle income countries, people will eat more meat and dairy products, causing a rapid growth in demand for agricultural commodities to feed livestock. Strong growth 
in demand over the past few decades has be driven particularly by rising consumption in China and Brazil, and the future trend is likely to be strongly influenced also by the extent of income growth in Sun-Saharan Africa, where per capita meat consumption is still very low (OECD/FAO, 2016).

The story is the same in Africa, as well as in other third World countries. The situation is even worse in this region because the demand for staple food is made by not just the middle class, but the lower class that can hardly afford to pay for their meal. But Nigeria with an estimated population of about 206 million is expected to face increased food security crisis as the population of Africa's largest black Country is expected to increase exponentially in the coming decade. (www.statista.com, 2020),

\subsection{Climate Change}

Bad weather, linked possible to global climate change, has hampered production in key food exporting countries. Severe weather events have impacted harvest from Australia to West Africa to Bangladesh and are now striking at America's heartland although we know that climate change is a factor, we know less about how it will shape specific global food outcomes in the near to medium term and what specific ameliorative steps to take today.

Climate change exacerbates natural disaster to contribute to the global food security crisis. This comes in the form of hurricanes, typhoons, flooding earthquake, etc. the impact of this is not most visibly felt in developing countries such as Nigeria, because they are ill-equipped to handle the problem. Although the recent flooding in parts of the country have been due to the opening of a dam in Cameroun, the problem was further exacerbates by climate change because there has been a general global rise in water levels. According to the then country's Minister of Environment, Mrs. Hadiza Mailafia, "the flooding we are experiencing in the country do not in any way fall into what you might term man-made. This is a natural phenomenon that cuts across the globe' (Adepegba, 2012).

\subsection{Underinvestment in Agricultural Production}

Agricultural concerns get little international and local attention when it comes to investment. It is not uncommon for international donor agencies to make contributions to various segments of development, leaving agriculture, which should be considered as a major development challenge. Because of this neglect also, grants are not given for research in agricultural technology to improve food production.

In Nigeria and other developing countries, government do not usually get involved with local farmers who are concerned with agricultural production. their efforts are thus left at a subsistence level, and the consequence is a production of food to take care of their immediate family, due to this low level of investments too, infrastructure such as roads, storage facilities fertilizers, and other incentives are not given to help local farmers boost their production.

Other causes of food security crisis: In Africa in particular, the incidence of armed conflicts and corruption/bad government also affect food security besides the financial resources and direct requirement necessary during war, armed conflict can cause food security crisis by disrupting farming process, direct destruction of vegetations and other food sources, cut off access to portable water and the destruction of wildlife this can have vary devastating consequences for food security in Africa.

Africa's abundant natural resources are plentiful enough to help it secure itself against the looming global security crisis. But rather than benefit Africans, these resources are carted away by corrupt African leaders. Additionally, in an attempt to perpetuate themselves in power, they use proceeds from these resources to fund civil wars and other crisis.

It is in line with this that the UN deliberated on natural Resources and conflict in Africa: Transforming $a$ Peace Liability into a Peace Asset (Legwaila, 2006). It was found that there was interconnectedness among issues of natural resource management, conflict and post-conflict peace-building in Africa. The role natural resources, 'blood' diamond and timber played in helping Charles Taylor execute his war efforts in Liberia and Sierra Lone. It is estimated that Taylor exported \$300 million worth of diamonds and \$53 million worth of tropical hardwood between 1990 and 1994, in the same period, he also made about $\$ 227$ million from rubber, and more \$16 million from iron ore (Moreno et al. 2007; Smillie, 2010). These monies could have been used to ensure that food security would have been achieved in the country rather than being used to cause devastation.

\section{STRATEGIC IMPLICAION OF FOOD SECURITY}

A number of security crisis are expected to result from global food security crisis. They include general insecurity, migration, health issues, and environmental degradation.

\subsection{Security Crisis}

It has been shown that there is a direct linkage between poverty and insecurity. A World Bank report among others showed that the poorest countries are most prone to violent conflict, while rapidly developing countries suffer fewer violent conflicts (Andrimihaja, 2011). We must also recall that at the time Afghanistan was used as 
the launch base for the greatest terror strike against the U.S., it was the second poorest country in the world (US War in Afghanistan, 1999). When poverty is rated, food is a significant aspect of this rating. This is because food is the most essential of all the commodities, insecurity results. As former U.S. President George W, Bush noted, "a world where some live in comfort and plenty while half of the human race lives on less than $\$ 2$ a day is neither just nor stable" (President's Inauguration speech, 2005).

That is why the World Bank Affirmed that "the elimination of global poverty is both a moral imperative and a necessity for a stable world" (Taylor, 2015). Although terrorists may not be said to impoverished, poverty (and indeed hunger) can create an enabling environment for terrorist to gain foothold and recruit foot soldiers. It is therefore not surprising that impoverished states such as Afghanistan, Somalia, Mali, etc. provide good environment for terrorism. Weak sate institution and weak governments are not always the cause for such phenomenon. Mali has recently been in the focus of the international community because Islamist connected with al-Qaeda-linked terrorist of the Algerian based Salafist Group for preaching and Combat (GSPC) has seized control of Northern Mali. We recall that Mali (with Ninety percent Muslim population and multiparty democracy since 1992), is an example of a well-governed country but suffers from poverty. This makes it vulnerable to the exploits of extremist groups. Mali has a gross national income per capital of $\$ 380$ and it is estimated that 72 percent of 12 million people live on less than $\$ 1$ per day. In 2005 Mali's human development ranked the fourth lowest in the World in 2005 (UNDP, 2005; World Bank, 2010).

A number of factors such as its poorly controlled borders, nomadic population, vast uninhabited spaces, and under-resourced security services render it an attractive recruiting, training and hiding place for the GSPC. It is Mali's poverty condition that renders it most vulnerable to terrorist infiltration. As a 2006 Jihadi magazine noted, Africa's poverty and social conditions "will enable the Mujahadeen to provide some finance and welfare" (Farah, 2006) and make their movement to Africa easy.

In Nigeria, the incidence of Boko Haram in Northern Nigeria has also been blamed to the prevalence poverty in various parts of the north. It is therefore no wonder that the Almajeris who live just to beg for the next meal are easy targets recruitment into the greatest security menace the country has ever know, which is Boko Haram.

Food insecurity was one of the causes of the Niger Delta crisis. This was because the Niger Delta environment was degraded by crude oil and other effluents and waste products associated with oil exploration. The people were thus unable to carry out their usual means of livelihood such as fishing and farming. Portable water was also affected by the activities of the oil extracting companies. As Tim Concannon explains: Compound the plight of the people of Niger Delta is the issue of environment pollution. Oil production and dredging have caused acid rain, fouled the air and the water, and caused widespread and dramatic erosion. Whole communities have watched their lands erode away. Fishing and farming, and traditional occupations of these people, is no longer viable. This situation has caused poverty hunger and desperation among these peoples, who are struggling to eke out a living (Concannon, 2011).

Besides environmental degradation, there are even cases where arable lands are forcibly take from the inhabitation of the Niger Delta without consideration to the food crisis this would cause for them and consequently for the whole country as their revolt resulted in a national security crisis. In one of the many such cases, Wibros, a pipeline contractor working for Shell in Ogoni bulldozed farmlands. In the protests that immediately followed that incident, one person was killed, while over twenty others were wounded (Concannon, 2011).

\subsection{Migration}

The already bad cases of food security are usually worsened by armed conflicts. In recent times phenomenon is worse in Africa as the continent has been consumed with national and intra-state conflict since African countries started getting their independence in 1960. This situation leads to migration, which then complicates food national security, and other security complications for places where these immigrates settle. For example, the Boko Haram crisis is Nigeria has been said to have been given impetus by Nigeriens, Chadians, Sudanese, and other foreign nationalist who were drawn into the country because of food insecurity and other crises is their own countries. As a result of his, Vanguard newspaper reported that in connection with the recent security threat posed by Boko Haram, Nigeria has recently repatriated over 11,000 foreigners (who are mainly citizens of Niger and Chad) in order "to curb a growing Islamist insurgency (Vanguard, 2012).

\subsection{Health}

Least Developed Countries (LDCs) and the poorer countries of the developing world are less able to handle related emergencies. This is because they lack the capability to prevent or carry out early detection or even treat their people. Meanwhile because their inhabitants do not have adequate food, their nutritional requirement is not met by their poor daily diet. They are therefore least able to fight diseases. These people are also more likely to provide conducive environment for these diseases to mutate and develop into more resistant strains 
The significant of this to global heath and security is that such diseases can spread to other countries or even across continents. It was based on this that the U.S. National Intelligence Council emphasized that: New and reemerging infectious diseases will pose a rising global health threat and will complicate U.S. and global security over the next 20 years. These diseases will endanger people at home and abroad, threaten foreign armed forces deployed overseas, and exacerbate social and political instability in key countries and regions (NTC, 2000).

Indeed, new infections disease H5N1 avian flu virus, West Nile virus, hepatitis C, SARS, etc have often originated in developing and LDCs with growing population that have acute food, water and arable land shortage. It is often more prevalent with families that practice substance livestock and arable farming because they live in close proximities with and animal (such as chickens, pigs goats cattle etc), they easily contact and transfer these diseases to others. According to the World Bank, by July 2006, the H5N1 virus infected both humans and animals in about 48 of the world's most impoverished and remote countries where food is one of the gravest concerns (WHO, 2005). As an example, he Democratic Republic of the Congo (DRC) with 71 percent malnourished population between 2000 and 2002 was in the same year declared an epicentre of diseases (WHO, 2006)

Mal-nourished children are more at risk to attack from diseases that their adult counterparts. This is because their body structure are yet to develop fully, this development requires nutrition that comes from food. According to UNICEF, 30,000 children die each day from illness, and that these children succumb to such disease due to poverty. It also noted that children living in the poorest 20 percent of homes are two to three times more likely to die than those living in the richest 20 percent of homes in the same countries (UNICEF, 2006). This shows the important position food can have in fighting illness

\subsection{Environment Degradation}

Poverty and food security crisis generally have a negative impact on the environment. This can come in a number of different forms. In Africa in particular, in an attempt to beat the dynamics of food security, there is the tendency for farmers to over-cultivate or over-graze a land. This process can lead to bush burning, which releases gases that harm the ozone layer. The continuous cutting and gathering of firewood, combined with an increase demand for arable land can accelerate deforestation.

Additionally, poor people generally are inefficient in their use of energy sources. They usually fell tree and use them for firewood and this can also releases a lot of pollutants into the atmosphere. This green house gases can also complicate health conditions in human and his livestock and generally affect environmental health (UNFPA, 2001).

Haiti is a good illustration of this problem. It typifies the relationship between poverty and environmental degradation. Haiti (the poorest country in the Western Hemisphere), has a per capita GDP of \$361. An estimated 65 percent of its population lives below the national poverty line. The popular source of fuel is firewood and charcoal. Charcoal is also made from trees that are cut down. Peasant farmers in Haiti affect the environment negatively by constantly cutting trees and other vegetation in order to feed their families. Associated Press estimated that about 30 million trees are cut down each year and this exacerbates and problem of environmental security. Haiti is about 90 percent more deforested compared to its immediate and richer neighbour, the richer Dominican Republic (AP. 2003) This situation escalated to civil unrest in the form of riots in Haiti.

The global consequences of deforestation are indeed severe. Erosion can increase flooding and causes the silting of waterways, while soil degradation reduces agricultural yield and thus increases hunger. Drought thus results from deforestation and the end result is also hunger and food security crisis.

\section{Food Security and COVID 19}

A good number of countries are experiencing growing levels of acute food insecurity which has reverse years of development gains. At the eve of COVID 19, there was dwindling incomes and disruption in the supply chain, chronic and acute hunger were manifesting due to different factors, among which are conflict, social-economic conditions, natural hazards, climate change and pest.

COVID 19 has led to severe and widespread increases in global food insecurity, affecting vulnerable households in almost every country, with impacts expected to continue through 2021 and into 2022 (World Bank, 2021 ). By January 2020 , global food prices rose by $38 \%$. Maize prices are $80 \%$ higher and wheat price rose by $28 \%$ more after January. These surging prices reflect strong demand, along with weather uncertainties, macroeconomics conditions and COVID 19 related supply disruptions, even though the global production outlook for major grains remains good. The basic risks to food security are at country levels: Higher retail prices, combined with reduced income, mean more and more households will have to temper with the quality and quantity of their food consumption (World Bank, 2021).

A good number of countries are experiencing inflation at retail level, reflecting the persistent supply disruptions as a result of social distancing measures, devaluation of currency and related factors. The rising global food prices have a greater impact on people in low and middle income countries. Evidence from World 
Bank Rapid phone survey in 48 countries signifies that a significant number of respondents indicate that people are running out of food or cutting down their consumption. It is recognised that reduction in calorie intake or compromised nutrition is a threat to gains achieved in poverty reduction and health; and this could produce adverse effects on the cognitive development of children. It is important to note that producers of food items are already counting their losses on perishable and nutritious food due to shift in consumption patterns towards cheap staple food. Even when the present food insecurity is however not resulting from food shortages, it has to be noted that disruption in supply and rising prices of main agricultural inputs - fertilizer and seeds, or prolonged labour shortages could diminish next season cropping/ harvest (World Bank, 2021).

Before COVID 19, there was indication of rising hunger. FAO estimated the number of undernourished (including those with chronic and acute hunger) to have increased from 624 million people in 2014 to688 million in 2019. The major driver to this trend was extreme climate events conflict and other shocks to economic opportunities. Not forgetting the implications of locust outbreak in 23 countries and other zoonotic diseases that are recurrent threat.

Between 2020 and April 23021 COVID 19 have increased the number of people affected by acute food insecurity to 296 in 35 counties without sufficient food; this 111 million more people than in April 2020 (WFP/FEWS NET, 2021). The World Bank has assisted counties to run community kitchens, restore fresh food supplies, provide cash and food support to vulnerable and high risk families through its Social Protection project.

\section{STRATEGIES TO IMPROVE FOOD SECURITY}

In order to sustainably reduce chronic insecurity, the global community which must include the developed and developing worlds, donor agencies, civil society must work together to ensure the following.

\subsection{Improvement in the Agricultural Sector}

The major challenge to food security in Africa is its underdeveloped agricultural sector that is characterized by over-reliance on primary agriculture, low fertility soils, minimal use of external farm inputs, environmental degradation, significant food crop loss both pre- and post- harvest, minimal value addition and produce differentiation and inadequate food storage and preservation that result in significant commodity price fluctuation. Ninety five percent of food in sub-Saharan Africa is grown under rain fed agriculture (IAC, 2004) Hence food production is vulnerable to adverse weather conditions. There is an overall decline in farm input investment including fertilizer, seeds, and technology adoption. Access to fertilizer use is constrained by market liberalization and trade policies that increase fertilizer prices relative to commodity prices, limited access to markets and infrastructure, limited development of output, input and credit markets, poverty and cash constraints that limit farmer's ability to purchase fertilizer and other inputs (Kheralla, 2006). The soils continue to degrade leading to a reduction in the productivity of the farms some of the causes of soil fertility depletion in Africa include the limited adoption of fertilizer replenishment strategies and soil and water conservation measures; the decline in the use and length of fallow periods; expansion of agricultural production into marginal and fragile areas; and the removal of vegetation through overgrazing, logging, development, and domestic use. Other causes include population growth, limited access to agriculture-related technical assistance, and lack of knowledge about profitable soil fertility management practices leading to expansion into less-favourable lands. A significant amount of food is lost through pre- and post- harvest losses. The tropical climate makes foods produced in these regions prone to pest and diseases. Poor handling and storage further increase the post-harvest losses. Management of the African agricultural system is further complicated by the existence of diverse heterogeneous system".

\subsection{Poverty Alleviation}

Poverty is one of the root causes of food insecurity, particularly in the developing countries. It is the major reason people are unable to gain access to food due to poverty (AIC, 2004). This is due to the rising cost of food and the lack of capital to invest in agricultural practice beyond the subsistence level for many people in the developing world, particularly in the Sub-Saharan Africa, to which Nigeria belongs. By alleviating poverty in the rural areas, rural farmers who form the bulk of national farmers would be able to buy improved seedlings, hire labourers to help out and even buy machineries.

\subsection{Improvement in Health Care Delivery}

One of the factors affecting rural farmers is inadequate health system. This is because agricultural practised at that level requires a lot of manpower as every aspects of the farming activity is manually carried out by either the head farmer, his family/in-laws and in rare cases hired labourers. This means that they must continuously be in good health to be able to contribute meaningfully and at all times.

Of all the health problems that affect farmers in the Third World countries and Africa in particular, the high prevalence of HIV/AIDs is the biggest. The pattern of HIV/AIDs distribution follows that of food security in the 
continent. Food security crisis is lowest in Northern Africa (4 percent) and highest in Central Africa (40 percent. This approximately corresponds to the distribution of the HIV/AIDs crisis in the continent). (Resegrant et al., 2005).

\subsection{Make Rural Development and Agricultural Productivity Foreign Policy Priorities}

The U.S. and other donor countries should make rural development and agricultural productivity a priority. These countries should make agriculture a priority for their foreign assistance strategy. They should set an official target to significantly increase agricultural productivity and rural development in the developing world, similar to the millennium development goals. This strategy will significantly reduce hunger, poverty, and malnutrition, not just in developing world but also in the developed world.

\subsection{Agricultural Policy on Food Production and Preservation}

The developing countries and LDCs must in addition to the above make efforts on their own to enhance agricultural production. Government of these countries must help farmers to acquire arable lands, fund farming processes and most importantly, help provide new ways to help with food storage.

Food storage is a limitation for farmers in the Third World countries. It is the reason many farmers do not attempt to go beyond subsistence agriculture because they would not risk to borrow money or make other risky investments concerning farming because they would have no way of storing excess crops and other food products that would be produced. When this is achieved, food security crisis particularly in the Third World countries would be minimized.

An example is the recent food insecurity that followed the flood disaster that affected about 20 states in Nigeria. In addition to displacing and killing many Nigerians, arable lands were also flooded, destroying cultivated lands in the process.

In Jigawa State, alone, no fewer than 400,000 farmlands and 36,000 houses were destroy by the flood (Attah, 2012). This destruction was not limited to arid land alone. In Cross River State, over 49 coastal communities in seven local government areas were also destroyed in one week. About 100 houses were destroyed, while 2,500 livestock were killed. The rising water level has caused the death of over eleven persons and hundreds of houses in the state (Affe, 2012). The Federal Government has come, although this gesture is commendable, it is still reactionary process that the Nigerian government should immediately set up a committee to come up with a technical report on agricultural enhancement particularly in the area of food preservation. The findings of this committee must also be implemented

\section{CONCLUSION}

There is a growing global food security crisis. This crisis is indeed global in the sense that affects the developed nations, the developing countries and the Third World Countries. This crisis is manifested by an increasing global food price hike, accompanied with shortage of staple food source and future cropping and harvesting. These have strategic implications for the nations of the world, affecting general security, and even the children and the environment. Concerted effort $\mathrm{s}$ are greatly required to stem the tide through social protection projects and deliberate targeting of vulnerable households

To curtail these problems, he following recommendations is therefore proffered:

1. Global security challenges such as terrorism are linked to food security crisis and poverty in general; therefore, current international and local efforts made toward eradication of terrorism should include food security.

2. The U.S. and other donor countries should make rural development and agricultural productivity a priority. It is only this is achieved that other associated developmental objectives in Africa and other Third World countries would become a reality:

3. Practical strategies to improve agricultural practices such as food shortage should be researched and developed. This is because food shortage is one of the major challenges developing countries face. In Nigeria, the recent flooding of some states lead to a hike in food prices in the country, showing the need for this.

4. Health care system should be improved upon in particularly the rural communities. This because majority of farming activities take place in these areas and this is done using manpower. Thus, any drop in the health conditions of the farmers is immediately manifested in their production. HIV/AIDs is the greatest threaten to the health of the rural worker.

5. Therefore is a linkage between the environmental degradation and food security. Therefore, efforts should be made to educate farmers on best practices to help curtail the destruction of the environment which will in the turn help ensure food security.

6. Poverty eradication and rural development should be made a priority. By so doing, farmers would be empowered to buy a improved seedling, hire labourers and even buy machineries for farming thereby 
boosting their productiveness

7. There should be a balance between current generation project such as the production and use of biofuel and food stuffs used to generate them. Thus, policies should be made to curtail the use of cereals for the production of these energy sources in the advanced countries.

\section{REFERENCES}

1. Adepegba, A. Everest Amafule \& Olalekan Adetayo, (2012), "Food Crisis Imminent FG", The Punch, Thursday, September 27,2012, P. 2

2. Affe, M. (2012), "Cameroon dam water destroys 49 communities" The Punch Monday, September 17, p. 12.

3. Alexendratos, N. A \& Bruinsma, J. (2012), "World Agriculture, Towards 2030/2050": The 2012 Revision. Global Perspective Study Team. FAO/UN. www.fao/economic/esa Accessed on March 15, 2021.

4. Andrimihaja, N. A. (2011), "Stop Conflict, Reduce Fragility and End Poverty". World Bank Group. www.worldbank.org Accessed on March 15, 2021.

5. Associated Press (2003), "Trees in Haiti Fall Victim to poverty of the people".

6. Attah, D. (2012), "Flood Destroys 400,000 farmlands, 36,000 houses in Jigawa":, The Punch Tuesday, September 18.

7. Beddington, J. (2013),"A Perfect Storm Scenario" Farming First; A Global Coalition for Sustainable Agriculture Agricultural Development. farmingfirst.org/2013/0

8. Beddington, J. (2009), "Food Energy, Water and the climate: A Perfect Storm of Global Events? HM Government Office for Science, London, p. 2.

9. Beddington, J. (No Date), “2030: the "Perfect Storm” Scenario" Population Institute, p. 2.

10. Carlos Pascual (2008), "Proceedings" in Weak and Failed States what they are, why they matter ad what to do about them" The Brooking Institution, Washington, D.C February 26, P. 2.

11. Centre for Strategic and International Studies (CSIS) (2008), "A call for a strategic U.S. Approach to the Global Food Crisis", A report of the (CSIS) Task Force on the Global Food Crisis Core Findings and Recommendations The CSIS Press, Washington, D.C, p. 4.

12. Centre for Strategic and International Studies (CSIS) (2019),|"Food Security: A Test of U.S. Leadership in a Frigile World". www.csis.org.ana Accessed on April 01, 2021.

13. Charles J. Godfray, J. R Beddington, Ian R. Crute, L. Haddad, D. Lawrence, J. F. Muir, J. Pretty, S. Robinson, S. M. Thomas \& C. Toulmin (2010), "Food Security: the Challenge of Feeding 9 Billion People", Science 327, vol. 812, , p. 815 .

14. Committee on World Food Security -CSF (2012), “Global Framework for Food Security and Nutrition". UN/FAO, Rome.

15. Concannon, T. (2011), "Resource Exploitation in Nigeria: Shell Fights fires over Niger Delta Oil Spill", AFRICAN VOICES ON DEVELOPMENT AND SOCIAL JUSTICE Pambzuka News 140, January 22.

16. Daviron B. \& Douillet, M. (2014), "Major Player of International Food Trade and the World Food Security". Colloque SFER $<<$ Agriculyure et geopolitique.

17. ENDA, 'Biofuel development in Africa' cited in Molony, T. \& Smith, J. (2010) Briefing, "Bio-fuels Food Security, and Africa”, African Affairs, Vol. 109 No. 436, A p. 498.

18. Farah, D. (2006), "Jihadist Now targeting Africa" (www.douglasfarah.com/archieve/2006-0601 archieve.shtml. Accessed March 23, 2021.

19. FAO, IFAD and WFP, (2014), "The state of food insecurity in the World 2014": Strengthening the enabling environment for food security and nutrition". Rome, FAO. http://www.fao.org/publications/sofi/2014/en/ Accessed March 15,2021.

20. Food and Agricultural Organization (2006), "Introduction in Inventory of Environment and Security policies and practices: An Overview of Strategies and Initiatives of Selected Governments, International Organization and inter-Governmental Organization. Quoted from Michael Renner, in Ronald A. Kingham (ed.) IES,The Hague, The Netherlands.

21. Food and Agricultural Organization (FAO) (2010), The State of Food Insecurity in the World: Addressing food insecurity in protracted crisis. FAO/UN, Rome.

22. Food and Agricultural Organization (FAO) (1983), “World Food Security: a Reappraisal of the Concepts and Approaches", Director General's Report, Rome.

23. Food and Agricultural Organization (FAO) (2012), "Corporation document repository, p.2., available online at: http//www/fao.org/docrep/005/y4671e06.ht. Accessed on March 12, 2021.

24. Food and Agricultural Organization (FAO) (1996), "Rome Declaration on World Food Security and World Food Summit plan of Action. World Food Summ, "The State of Food insecurity in the Word 200"1, Rome..

25. Glenn Ashton, (2012), "In Africa, A perfect Storm for Food Security. available online at: http://www.desdemonadespair.net/2012/09/in-africa-perfect-storm-for-food.html, accessed on March 12, 
2021

26. Hashmi, A.A., M.H. Sial, W. Akram and M.H. Hashmi. (2018), "Assessing food insecurity trends and determinants by using mix methods in Pakistan: Evidence from household pooled data (2005-2014). Sarhad Journal of Agriculture, 35(1): 87-101. DOI | http://dx.doi.org/10.17582/journal.sja/2019/35.1.87.10, accessed on March 13, 2021.

27. IFPRI. (2014), (2013) "Global food policy report, IFPRI”. Accessed from IFPRI: March 14, 2012.

28. IFPRI, (2016). (2016 Global Food Policy Report, IFPRI”. Accessed from IFPRI: March 14, 2021.

29. Inter Academy Council (2004), "Realizing the promise and potential of African Agriculture." Amsterdam.

30. Kherallah, M., C., Delgado, E., Gabre-Mahin, N. Minot, \& M. Johnson (2006), "Reforming Agricultural Markets in Africa." Washington DC. The Johns Hopkins University Press.

31. Legwaila, J. L. (2006), "Natural Resources and Conflict in Africa: Transforming a Peace Liability into a Peace Asset". Cairo Egypt 12 - 19 June.

32. Lian P. K. \& J. Ghazoul (2008), "Biofuel, biodiversity, and people: understanding the conflicts and finding opportunities"; Biological Conservation 141, 10 pp. 2450-60.

33. Ilaboya, I.R.; F.F. Asekhame; M.O Ezugwu; A.A. Erameh \& F.E. Omofuma 2010) "Studies on Biogas Generation from Agricultural Waste; Analysis of the Effects of Alkaline on Gas Generation", World Applied Science Journal Vol. 9, No. 5. P. 537.

34. Malpass, D. (2021), "President's Remarks on Corona virus (COVID 19) and Food Security" Vulnerability Analysis and Mapping. www.Worldbank.org/en/topic accessed May 23, 2021.

35. McClain, N. (2004), "Implementing a Human Rights Approach to Food Security, 2020 Africa Conference IFPRI, Policy”, Policy Brief 13.

36. Mitchell, D. (2011),'Biofuel in Africa: Opportunities, Prospects and Challenges”. The World Bank, Washington D. C.

37. Molony, T. \& J. Smith (2010), Briefing, "Biofuels Food Security, and Africa", African Affairs, Vol. 109 No. 436, A p. 498.

38. Mwaniki, A. (2009), "Achieving Food Security in African: Challenges and Issues", United Nations, Geneva, p. 1.

39. National Intelligence Council (NIC), (2000)," The global infectious diseases threat and is implication for the United States, p, 5.

40. OECD/FAO (2016) OECD/FAO Agricultural Outlook 2016 - 2025; Agriculture in Sub-Saharan African: Prospects and Challenges for the Next Decade. http://www.fao.org Accessed on March 31, 2021.

41. Office of the Press secretary white House "Remark by the president to the World Bank" on July 17, 2001 available online at: http://www.whitehouse.gov/news/release/2001/07/20010717-1html. Accessed March, 2021

42. Osawe, A. I., F. O. Akhimien, \& E. I. Aigbokhaebho (2015), "The Impact of Climate Change on Food Security and Rural Livelihood in Nigeria”. Ekpoma Journal of Social Sciences, Vol. 6, No. 1, June.

43. Oxfam, (2008), "Another inconvenient truth: How Biofuel Policies are Deepening Poverty and Accelerating Climate Change”, Oxfarm Brief Paper 114. www.ofam.org Accessed on April 02, 2021

44. Rosegrant, M.W., S. A. Cline, W. Li, T. B. Sulser, R. A. Valmonte-Santos (2005), "Looking Ahead. Longterm prospects for Africa's Agricultural Development and Food Security”. Washington D.C.: IFPRI

45. Sekoai, P. T. (2016), "Biofuel Development Initiative in Sub-Saharan Africa" - MAPI. www.mpi.com Accessed on March 31, 2021.

46. Simillie, J. (2010), "Blood on the Stone: Greed, Corruption and War in the Global Diamond Trade." Anthem Press. www.anthem.press.com

47. Stephen, E. (1999), "The Mask of Anarchy, Hurst and Company”, London, opp. 90-91.

48. The World Bank et al., (2000), "Global poverty report "G* Okinawa summit, July, p. 1. Available online at: http//www/wordbank.org/html/extdr/extme/G8poverty2000pdf. Accessed on March 23, 2021.

49. United Nation Development program, (2005) Human Development Report 2005 (New York: United Nations. (http://hdr.undp.org/reports/globa2005pdf/HDR05-HDI.pdf December 2006). Accessed on March 23, 2021

50. United Nations Children's Fund- UNICEF (2006), "State of the World's Children 2006 Excluded and invisible." New York United Nations, p. 20.

51. United Nation Population Fund (UNFPA) (2001), "Development levels and environmental impact" In UNFPA (Ed.) The state of world population (2001, (chapter 3). UNFPA New York.

52. United Nations conference on Trade and Development (2008), "Addressing the Glo al food crisis key trade, investment and commodity policies in ensuring sustainable food security and alleviating poverty United Nations, New York, P. 1.

53. UN, United Nations Expert group (2006), "Meeting on "Natural Resources and Conflict in Africa: Transforming a peace Liability into a peace Asset" Conference Report, 17-19 June Cairo, Egypt 
54. United Nations (UN), “(1975) Report of the World Food Conference,” Rome 5-16 November 1974, United Nations, New York:

55. Van Dijk, M. (2011) “African Regional Integration: Implications for Food Security "EL and I, March 3, 29pp.

56. Vanguard.(2020), "Boko Harem: Nigeria Repatriates 11,000 Aliens" March 1.

57. Wiesmann, D. (2007), "Is food insecurity more severe in South Asia or Sub-Saharan Africa? A comparative analysis using household expenditure survey data (Vol. 712). IFPRI, Washington, D.C.

58. World Bank (2021), "World Bank Commodity Prices And Agricultural Market Information System" (AMIS) www.worldbank.org Accessed May 23, 2021.

59. World Bank (2021), “Keeping Africa's Food Supplies Strong during COVID-19: Lessons from Past Crisis". www.worldbank.org accessed May 22, 2021.

60. World Bank (2003), "Breaking the Conflict trap: Civil war and development policy” (A World Bank Policy Research Report), (Washington D.C and New York: World Bank and Oxford University Press.

61. World Food Summit (1996), "cited in Food and Agricultural Organization (FAO), "Food Security", Policy Brief, Issue 2.

62. World Health Organization-WHO (2005), “Weekly Epidemiological Record," March, www.who.int/wer/2005/wer8010 Accessed on March 12, 2021.

63. World Health Organization-WHO (2006), “Weekly Epidemiological Record,” June 23. www.who.int/wer/2006/wer. Accessed on March 12, 2021

64. . (www.statista.com, 2020). Accessed on March 13, 2021. 